\title{
Editor's introduction Media and information literacy research in countries around the Baltic Sea
}

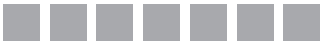 \\ Maarit Jaakkola \\ ORCID: 0000-0001-9979-6157 \\ UNIVERSITY OF GOTHENBURG, SWEDEN
}

https://doi.org/10.19195/1899-5101.13.2(26).1

This special issue of the Central European Journal of Communication (CEJC) collects studies on media literacy from countries around the Baltic Sea. The focus of the issue is on media literacy and related research in Poland, Estonia, Latvia, Lithuania, Finland, Sweden, and Russia. The main objective is to inquire into media education and literacy in local conditions within a specific geo-cultural area. This study of the applications of media literacy in its local variants is intended to contribute to our understanding of media literacy in diverse cultural contexts (FrauMeigs, 2007). The inquiry is also pertinent to the ongoing project of contesting the western epistemic center of media studies (Park \& Curran, 2000), by focusing on the northeastern corner of Europe, which is characterized by countries with small media markets and a limited number of users of national languages.

Indeed, the area around the Baltic Sea is an interesting border zone because countries in immediate vicinity to each other show very different and asynchronous development when it comes to the development of media literacy. In some countries, such as Finland, Sweden, and Poland, raising citizens' awareness and competence in terms of media and communication has been a public concern for a relatively long time, whereas the Baltic countries have been subjected to propaganda and other restricting conditions that have hindered the systematic advancement of critical media literacy and related agency until recently (del Mar Grandío, Dilli, \& O’Neill, 2017; Frau-Meigs, Velez, \& Michel, 2017; Frau-Meigs \& Torrent, 2009). According to the Media Literacy Index 2019, compiled by the European Policies Initiative of the Open Society Institute in Sofia, which assesses the resilience potential to disinformation in 35 European countries, using the level of media freedom, education, and trust in people as indicators, Finland (\#1), Sweden (\#4), and Estonia 
(\#5) are considered the countries best equipped to withstand the impact of "posttruth" and "fake news." Latvia (\#17), Poland (\#18), and Lithuania (\#19) are rated as less resilient and even show trends of deterioration when it comes to corruption and citizens' trust in journalists and experts (Lessenski, 2019).

The ambition of this issue is that we turn these differences into an opportunity and endorse the uneven development as something that provides the conditions for learning from each other and exchanging ideas and practices. Nevertheless, it cannot be ignored that media literacy issues are typically embedded to a high degree in local - that is, national or regional - conditions. Policies are prepared as part of the national political agenda, and best practices, whether in formal education or civil society activities, are typically exchanged at national or regional forums where authorities, associations, and local committees tend to operate. Not the least, media literacy is, to a large degree, related to questions of language. The mix of different national and minority languages, as well as different societal and media systems, have made it relatively difficult for the countries around the Baltic Sea to find a common framework for mutual cooperation and exchange. Neither West nor East has turned out to be successful concepts in this regard. The Western point of view has perhaps had the tendency of seeing the Eastern countries as apprentices, overshadowing the characteristics of the post-Soviet countries that might cause them to draw on resources and capacities that make them globally interesting and unique. Accordingly, post-Soviet frame in Eastern European countries, or countries in transition, may sometimes be experienced as rather obsolete or uncomfortable, bringing forth internal tensions and questioning the value of looking at the past versus looking to the future.

In this issue, we seek to examine, with the help of recent research, how media literacy is and has been formed in the Baltic Sea region in terms of policy, implementation, and pedagogy. As media literacy pedagogy is being richly advanced in different contexts, not the least in teachers' and adult education, our focus lies on policy and its implementation in the countries in question. By doing this, we hope to provide perspectives into media literacy research from the Eastern European countries, both to researchers themselves and beyond this relatively limited research community. As the very concept of "media literacy" is only a couple of decades old, media literacy studies still constitute a young area of inquiry within the academy, both in research (see e.g., De Abreu, Mihailidis, Lee, Melki, \& McDougall, 2017) and education (see e.g., the Swedish Media Council, 2019; Salomaa, Palsa, \& Malinen, 2017). Media literacy research has the important task of developing the theoretical ground for addressing media literacy as an epistemological and discursive construct and of discovering patterns and models that cannot be easily observed from policy and pedagogy areas. As an interdisciplinary object of inquiry, drawing the most strongly on media, journalism, and communication studies; pedagogical studies; and many interdisciplinary fields, such as youth, cultural, and game studies, media literacy studies are scattered across different institutional settings within the academy. Clusters of media literacy research typically 
emerge at teacher education institutions within pedagogical studies, and in media, communication, and journalism studies, as well as in the disciplines of psychology and sociology.

Still, given the many entries into the academic sphere of questions related to media literacy, it might often be difficult to determine who actually is a "media literacy researcher." Researchers typically have other primary research interests growing from the foundations of their disciplines than the object of literacy, and media literacy only presents a temporary stop on their path towards some other knowledge. Another, slightly sensitive, dimension of media literacy research is that the fine line between researcher and policymaker has been sometimes drawn in the sand. When researchers have been open to giving guidance, consulting is what has been expected from them. However, by advancing (critical) media literacy research within the academy as an endeavor separated from policy and pedagogy, we add to the body of evidence-based knowledge that benefits society at large. Investing in media literacy research protects public discussions on this richly addressed topic from being opportunistic and led by personal opinions and tastes, or from being overdramatized, overgeneralized, or seen as the "magical panacea" to everything that Buckingham (2019) aptly diagnoses "solutionism." While raising media literacy in the population may have long-term benefits in societies, media literacy cannot be the sole solution to the erosion of democracy or similar large-scale problems.

\section{A BOUNDARY OBJECT}

A Swedish and Finnish proverb says that a beloved child has many names. This is entirely true, at a general level, in relation to media literacy, which has in recent decades developed into an area in which a diversity of parallel, concurring, and even contradictory vocabulary is flourishing. Whenever we address the question of media literacy, or media education, we encounter a perplexing complexity. In this text, I use "media education", "media literacy" and "media and information literacy (MIL)" as the overarching terms, reflecting the diversity of the vocabulary in use, while aware of the effects of the different nuances that the choices of terms have.

Indeed, the terms "media education" and "media literacy" are often used in parallel ways and even interchangeably. At the same time, parallel concepts related to "competence" or "skill" occur, resonating with international discussions on terms with varying epithets, such as "critical," "digital," "multimodal," "dynamic," "trans-," "multi-," and so on. In many cases, the adopted term may represent a change from how media education or literacy has been defined earlier, as in the "new," "augmented," or "extended" literacies. Indeed, in many cases, the new terminology has resulted from a scholarly discontent with the existing terminology to describe the complexity of today's media landscape, and, in this respect, the chameleonic terminology testifies to the changes in the environment in which we 
are living. Scholars have attempted to extend the media literacy concept in order to detach it from the individual skills perspective to cover groups, communities, and organizations (Grizzle \& Hamada, 2019), or from written texts to cover multiple media channels and modes (the New London Group, 1996; Frau-Meigs, 2012). At the same time, there are more limited terms referring to a specific subtype of media - for example, film literacy, visual literacy, or technology literacy (Stordy, 2015; Tyner, 1998; Carlsson, 2019). Different sectors of governance and practice have adopted concepts that best suit their purposes, thus accentuating different dimensions of media- and information-related literacy. For example, in Finland, the formal education policy has recently adopted the term "multiliteracies" to the school curricula (Rasi, Kangas \& Ruokamo, 2019), and youth work has endorsed "digital skills" or "competencies" related to the overarching concept of "digital youth work" (digitaalinen nuorisotyö) (Lauha \& Tuominen, 2018), while the national policies are still connected to the terms "media literacy" and "media education" (Ministry of Culture and Education in Finland, 2019; 2013). In Estonia, the youth work sector has been introduced to the very specific concept "smart youth work" (nutikas noorsootöö) (Estonian Youth Work Centre, 2013), with a focus on the use of information and communication technology (ICT) and promoting digital skills and solutions related to this area.

One might trivialize the question of vocabulary by saying that words are only words; however, it cannot be overlooked that terms can carry strong connotations and guide the actions of agents, even though they may be unconscious of their impact. Thus, the dominant terms that have been established as core concepts in any given sphere of action may play a crucial role towards determining what dimensions of media literacy are seen as substantial in implementing goals and how media literacy activities are shaped. On the other hand, what is interesting about the concept of media literacy as constituting a basis for action is that it presents an irresistibly multi-functioning concept to be harnessed in societal debate - the importance of which is relatively hard to question. Media literacy, in all its variations, can aptly be described as a "boundary object" (Star \& Griesemer, 1989), a concept shared by different communities in discourse but understood differently in each of them. Boundary objects are seen as particularly valuable as they link different communities and allow different groups to collaborate (Wenger, 1998; Ilomäki et al, 2016). Despite its emptiness and inaccuracy, "media and information literacy," or any of its variants, thus seems to work as an entry point for cooperation in the complex multi-stakeholder field in which media education unfolds.

Furthermore, what is particularly interesting about the boundary object that media literacy has formed into is its resilience to the rapidly changing media landscape. It is true that different processes of media reception and production, and mixed forms of them, have become more diverse and complex. Receiving content is no longer a question of analyzing it according to fixed, relatively stable structures, such as by understanding the genres and styles of an institutionally 
pre-made order, and, thus, the former, solid epistemological basis of all content has started crumbling. Working with content includes the processes of archiving, organizing, sharing, curating, moderating, commenting, editing, and modifying, in different positionings of produsage (Bruns, 2016) or prosumption (Toffler, 1980 ), in which the skills related to the creation of content and entire media play an increasingly significant role. Or, to state it more dramatically, we could suggest that we are, in fact, undergoing a radical change that affects the essence of how the essential preconditions for media literacy are being re-configured. First, there are changes in the environments in which media "happens," namely in the production spaces; second, the agency connected to receiving and producing media content, the agency of acting and producing content in mediated environments, is changing; and, third, the contents of different media are being mashed up and blurred, and the boundaries between commercial and non-commercial messages and intentions are becoming hard to maintain, which is described by Einstein (2016) as "content confusion."

Still, despite these fundamental developments, the early definitions of the umbrella terms "media literacy" and "media education" are still pretty much valid, even if the terms "media" and "literacy," as well as the many other terms designed to replace literacy, have been sometimes experienced as highly problematic, due to, for example, ignoring users' popular culture pleasures or being too optimistically connected to democratic and egalitarian aims (see e.g., McDougall, 2017; Merrin, 2014, Buckingham, 1990). The basic definition of media literacy as the "ability to access, (evaluate), analyse and create media" (UNESCO, 2013; Livingstone, 2004; Aufderheide \& Firestone, 1993) more or less persists, identifying the access to, evaluation, and analysis, as well as (content) creation of media, as key ingredients of media literacy and education (see also NAMLE, 2020). The objective of media education can still, to a great extent, be found in "developing greater critical awareness among listeners, viewers and readers" and consequently, "greater competence" among them (UNESCO, 1983) when contacting media of any kind. Fundamentally, the mediatic processes of encoding and decoding that constitute people's relationship to media are still present (see e.g., Masterman, 1985).

Therefore, media literacy can essentially be seen as an instrument to assist people in creating agency that helps them to be informed and capable of acting in constantly changing and increasingly mediated environments. This is the definition taken as the starting point of this special issue, in which the focus is not so much on changes in media and the effects of these changes on media literacy than on continuities in policy and pedagogical practice viewed over time.

\section{MEDIA LITERACY IN NORTHEASTERN EUROPE}

Media literacy research is formed in accordance with the national policies, implementation practices, and pedagogical models in the country in question. The core 
concepts in the Baltic Sea region vary, and have varied over time, in alignment with changes in media and education environments. Table 1 shows the most common terms used in the countries around the Baltic Sea, showing both the English and original language terms. The table is not exhausting and does not capture the de facto diversity in each country but, instead, attempts to identify the dominant terms used in the sectors of governance (national policies closest to "media literacy"), schools (as an example of the implementation of national policy), and civil societies (understood as the field of associations and non-formal education). In each of these spheres, there is naturally a great variation of concepts.

Table 1. Central terms used in Baltic Sea countries to refer to media education/literacy

\begin{tabular}{|c|c|c|c|c|}
\hline Country & $\begin{array}{c}\text { Official } \\
\text { language }\end{array}$ & Government & School & Civil society \\
\hline Estonia & Estonian & $\begin{array}{l}\text { Media (and communica- } \\
\text { tion) education } \\
\text { (meedia[- ja kommuni- } \\
\text { katsiooni-]haritus, } \\
\text { meediakasvatus) }\end{array}$ & $\begin{array}{l}\text { Communication } \\
\text { competence (suhtlus- } \\
\text { pädevus) and digital } \\
\text { competence (digitaalne } \\
\text { pädevus), information } \\
\text { environment (teabekesk- } \\
\text { kond) as cross-curricu- } \\
\text { lar topic }{ }^{2}\end{array}$ & $\begin{array}{l}\text { Media competence } \\
\text { (meediapädevus), } \\
\text { media (and informa- } \\
\text { tion) literacy (meedia- } \\
{[\text { ja info]kirjaoskus) }}\end{array}$ \\
\hline Finland & $\begin{array}{l}\text { Finnish (F), } \\
\text { Swedish (S) }\end{array}$ & $\begin{array}{l}\text { Media education } \\
\text { (F: mediakasvatus, } \\
\text { S: mediefostran), } \\
\text { media literacy } \\
\text { (F: medialukutaito, } \\
\text { S: mediekunnighet) }\end{array}$ & $\begin{array}{l}\text { Multiliteracy (moniluku- } \\
\text { taito })^{5}\end{array}$ & $\begin{array}{l}\text { Media education } \\
\text { (mediakasvatus), media } \\
\text { competence } \\
(\text { mediataidot })^{6}\end{array}$ \\
\hline Latvia & Latvian & $\begin{array}{l}\text { Media literacy } \\
(\text { medijpratība, mediju } \\
\text { pratība })^{7}\end{array}$ & $\begin{array}{l}\text { Digital literacy (digitālā } \\
\text { pratība })^{8}\end{array}$ & $\begin{array}{l}\text { Media literacy } \\
(\text { medijpratība })^{9}\end{array}$ \\
\hline Lithuania & Lithuanian & $\begin{array}{l}\text { Media and information } \\
\text { literacy (mediju ir } \\
\text { informacinis } \\
\text { raštingumas) })^{10}\end{array}$ & $\begin{array}{l}\text { Media and information } \\
\text { literacy (mediju ir } \\
\text { informacinis } \\
\text { raštingumas) })^{11}\end{array}$ & $\begin{array}{l}\text { Media and information } \\
\text { literacy (mediju ir } \\
\text { informacinis } \\
\text { raštingumas), media } \\
\text { literacy (mediju } \\
\text { raštingumas) }\end{array}$ \\
\hline Poland & Polish & $\begin{array}{l}\text { Digital competence } \\
\text { (kompetencje cyfrowe) }\end{array}$ & $\begin{array}{l}\text { No core concept; attached } \\
\text { to use of information and } \\
\text { problem solving }^{14}\end{array}$ & $\begin{array}{l}\text { Media education } \\
(\text { edukacja medialna })^{15}\end{array}$ \\
\hline Russia & Russian & 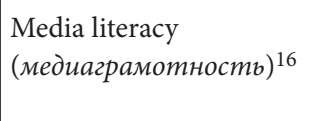 & $\begin{array}{l}\text { No core concept; media } \\
\text { education } \\
(\text { медиаобразование) })^{17}\end{array}$ & $\begin{array}{l}\text { Media education } \\
(\text { медиаобразование })^{18}\end{array}$ \\
\hline
\end{tabular}




\begin{tabular}{|l|l|l|l|l|}
\hline Sweden & Swedish & $\begin{array}{l}\text { Media and information } \\
\text { literacy (medie- och infor- } \\
\text { mationskunnighet, MIK) }\end{array}$ & $\begin{array}{l}\text { Digital competence } \\
\text { (digital kompetens) })^{20}\end{array}$ & $\begin{array}{l}\text { Media (and informa- } \\
\text { tion) literacy (medie- } \\
\text { [och informations]- } \\
\text { kunnighet, } \text { MIK), } \\
\text { digital competence } \\
\text { (digital kompetens) }^{21}\end{array}$ \\
\hline
\end{tabular}

1 Kõuts-Klemm et al. (2019).

2 Ministry of Education and Research in Estonia (2014).

3 See e.g., Ministry of Education and Research in Estonia (2020).

${ }^{4}$ Ministry of Culture and Education in Finland (2019; 2013).

${ }^{5}$ Finnish National Agency for Education $(2019,2018,2014)$.

${ }^{6}$ See e.g., Palsa et al. (2014).

7 Ministry of Culture in Latvia (2016).

8 Cabinet of Ministers of Latvia (2018).

9 See e.g., State Police of Latvia et al. (2018).

${ }^{10}$ Ministry of Culture of the Republic of Lithuania (2019).

${ }^{11}$ Ministry of Education and Science in Lithuania (2017)

12 See e.g., Lithuanian Journalism Centre (2019).

13 Ministry of Funds and Regional Policy in Poland (2014)

${ }^{14}$ Ministry of National Education in Poland (2017).

15 See e.g., Modern Poland Foundation (2020).

${ }^{16}$ Ministry of Digital Development, Communications and Mass Media of the Russian Federation (2019).

17 Fedorov (2008); Pedtehno (2016); Fedorov (2002).

18 Government Offices of Sweden (2018); Carlsson (2019).

${ }^{19}$ Government Offices of Sweden (2018); Carlsson (2019).

20 Swedish National Agency for Education $(2018,2019)$.

${ }^{21}$ See e.g., The Swedish Press and Broadcasting Authority and the Swedish Media Council (2017).

The most significant difference in terminology is between individual- or competence-based and activity-based concepts. Individual-based terms, such as competence, skill, and literacy, set the focus on the characteristics to be acquired, while activity-based terms, such as education, emphasize the processual nature of media literacy, or the activity of pursuing these competencies, which are often defined top-down. While the term "media education" has, for a long time, played a central role in countries with a longer tradition, such as in Finland (mediakasvatus), Estonia (meediakasvatus, meediaharidus), Poland (edukacja medialna), and Russia (mediaobrazovanie), the UNESCO-led concepts of "media literacy" and "media and information literacy" have gained a stronger foothold in Sweden (mediekunnighet, medie- och informationskunnighet), Latvia (medijpratība, mediju un informācijas pratība), and Lithuania (mediju ir informacinis raštingumas) as the core terms permeating different societal spheres. Recent developments have also established the literacy concept as a parallel notion (medialukutaito, media- ja informaatiolukutaito in Finland; meediapädevus, meedia- ja infopädevus in Estonia; mediagramotnost', media-informatsionnaya gramotnost' in Russia). 
International actors, such as UNESCO (see e.g., 1983, 2013, 2015) and the European Union, have repeatedly underlined the importance of media literacy (see e.g., European Parliament, 2008; European Parliament and the European Council, 2018), giving member states an impetus to form national strategies. Typically, media literacy issues are scattered around the different sectors of governance and seen as cross-sectoral issues. National policies focused on media literacy, therefore, have the advantage of unifying the conceptual thinking on media literacy and education, and they are also apparently expected to lead the implementation of that concept. We might suggest that ideally the spheres addressed in Table 1 would be aligned with each other and point to the same direction, different areas of action complementing each other, but as media literacy is often not centrally governed and coordinated, this is typically not the case.

In the Baltic Sea region, Finland and Latvia have included media literacy in their ministerial-level policies the most powerfully. In Finland, the first policy document was published in 2013 by the Ministry of Culture and Education and updated in 2019, after a dialogical process with stakeholders. The new policy sets three primary objectives related to the scope, content, and character of media education: the media education provided in Finland shall be "comprehensive in terms of its content, perspectives, target groups and geographic distribution" (p. 14), "highquality, meaningful and non-discriminatory" (p. 16), and "systematic and consistent" (p. 18) (Ministry of Culture and Education in Finland, 2019). These elements were already present in the previous policy, in which the objectives of sustainable and cooperation-based child- and youth-centered media education were recorded, together with the explicit aim of assigning Finland a role as an active global promoter of media literacy (Ministry of Culture and Education in Finland, 2013). In Latvia, the first media policy document foreseeing activities in media literacy was published in 2016 by the Ministry of Culture. The mass media policy guidelines (Ministry of Culture in Latvia, 2016) set down the objectives for a well-informed audience: media literacy skills among the audience should "promote the creative activity of an individual, as well as reduce one-direction influence of mass media communication, allowing to identify and prevent the distribution of biased information" (Ministry of Culture in Latvia, 2016, n.p.). The promotion of media literacy is not yet explicitly supported by school curricula, in which "digital literacy" constitutes the core concept, which may undermine the efficiency of promotion activities (Ločmele, 2019).

At the point of writing this text, Sweden and Russia are re-working on their media literacy policies. In Sweden, after the government's democracy strategy had addressed the problem of factors threatening democracy, such as disinformation, propaganda, and online hate (Government Offices of Sweden, 2018), the Ministry of Culture launched a national investment in media and information literacy at the national level (Ministry of Culture in Sweden, 2018). The process is ongoing and is expected to result in a clearer profiling of the Swedish Media Council as 
the coordinating media authority of media literacy stakeholders. Consequently, media and information literacy is closely attached to the discourse on democracy and citizenship (see also Carlsson, 2019). In Russia, the current Ministry of Digital Development, Communications and Mass Media has made media literacy to one of the priority areas for the development of the media industry (Ministry of Communications and Mass Media of the Russian Federation, 2014), and these criteria are currently being updated. In addition, a program has been launched to introduce the basics of media literacy into training courses and programs higher education institutions, universities, and pedagogical institutes. (Ministry of Digital Development, Communications and Mass Media of the Russian Federation, 2019.)

In comparison, media literacy seems less integrated in the national media policy frameworks in Estonia and Poland. A recent panel assessing the media policy in Estonia suggested that the improvement of media and language education should be a better-prioritized aspect in media policy (Kõuts-Klemm et al., 2019). According to the panel's assessments, the "strategy documents should pay much more attention to the media and media communication education." They viewed media education as primarily related to strategic communication and advocacy, marketing communication, and general information literacy (Kõuts-Klemm et al., p. 25). Poland powerfully subscribes to a digital competence framework, supported by the Digital Poland Programme 2014-2020, which is financed by the European Commission and public or private funds (Ministry of Funds and Regional Policy in Poland, 2014). This program connects digital skills to the development of public e-services and e-governance, coupled with the development of civil society through individuals' digital skills and the digitalization of social life and public services.

In formal school curricula, media literacy has established its position as a crosscurricular theme instead of a special, isolated subject in the Baltic Sea region. In Finland, "multiliteracy" was introduced as a component of transversal competence in the national core curriculum for yearly childhood education (Finnish National Agency for Education, 2018), basic education (Finnish National Agency for Education, 2014), and upper secondary school education (Finnish National Agency for Education, 2019). Multiliteracy replaced the term "communication and media competence" ( $v i$ estintä- ja mediataito) in the previous core curriculum (for basic education, see Finnish National Agency for Education, 2004). In the new curriculum, multiliteracy is one of the seven cross-curricular topics, along with "thinking and learning to learn," "cultural competence, interaction and expression," "taking care of oneself and everyday skills," "ICT competence," "work-life skills and entrepreneurship," and "participation, influence and building a sustainable future." It is defined as "the skills needed to interpret, produce and evaluate different texts," based on a broad definition of a text, in order to "help pupils understand the diverse cultural forms of communication as well as build their own identity" (Finnish National Agency for Education, 2014; translation by the author). (Rasi, Kangas \& Ruokamo, 2019; see also the New London Group, 1996.) 
In the Baltic countries, media education was first introduced in the Estonian national curriculum in 2002 (Ugur \& Harro-Loit, 2010). The national curricula for basic and upper secondary schools (2014) include "communication competence" and "digital competence," among eight general competencies, the other six being "cultural and value competence," "social and citizen competence," "self-management competence," "learning to learn competence," "mathematics, natural sciences and technology competence," and "entrepreneurship competence." "Information environment" is one of the eight cross-curricular topics, the aim of which is "for the pupil to develop into an information-conscious person who senses and is aware of the surrounding information environment, is able to analyse it critically and acts according to his or her aims and society's communication ethics." Reflecting the ideas of critical media literacy and digital competencies, the underlying concept is information society.

Poland does not employ any single core concept in the school curricula to explicitly refer to media literacy or education (see also Brosch, 2017; Ptaszek \& Lysik, 2018). In the primary school curriculum, among the seven most important skills mentioned are "search, structuring, critical analysis and use of information from various sources" and "creative problem solving in various fields by consciously using methods and tools derived from the computer science, including programming" (Ministry of National Education in Poland, 2017, p. 12). These skills can be described as closest to information literacy skills, connected to the source criticism and use of information and communication technology (ICT). The understanding of media literacy is thus limited to information literacy and crystallized as the skills of "information use" (wykorzystanie informacji) and "problem-solving" (rozwiazywanie problemów). Information and digital competences clearly reflect framework put forward by the Digital Poland Programme (Ministry of Funds and Regional Policy in Poland, 2014).

In environments beyond the formal institutions, such as in the market and in civil society, many of the agents practicing media education are not aware of or do not connect their activities to the umbrella terms "media education" or "literacy." This is often the case with journalists who tend not to regard themselves as media educators but are more likely to see media education and literacy activities as part of their overall journalistic mission in the public interest and for the common good (Huovinen, 2019; Kakkola, 2009). In civil society, MIL stakeholders tend to approach the field through more specific and limited, and thus more concrete, concepts, such as source criticism, fact-checking, fake news, child safety, online risks, digital skills for senior citizens, hate speech, filter bubbles, or echo chambers (e.g., in Sweden, see the Swedish Press and Broadcasting Authority and the Swedish Media Council, 2017). The avoidance of terminology connected to academic and political language might be a pragmatic strategy to escape the elusiveness that the term media literacy evokes, and, in this way, to attempt to make the activities more appealing and approachable to the general public. 


\section{ARTICLES IN THIS ISSUE}

This special issue was produced in conjunction to the European Union Erasmus+ Strategic Partnership project "Media and Information Literacy \& Innovative Teaching Methods Laboratory" (MIL+LAB). The articles for this special issue were collected via an open call and accepted after an anonymous double-blind review, after the international conference TransMIL: Crossing boundaries in pedagogy, policies and practices of media and information literacy (MIL) organized in January 2019 at the Latvian National Library in Riga. The main output of the MIL+LAB project will be a joint master's program in media literacy, launched in fall 2020 between universities in the Baltic countries and Poland - Riga Stradins University, University of Tartu, University of Vilnius, and University of Wroclaw.

As media literacy is always more or less a derivative of the media practices observed in reality, media literacy, as a pedagogical concept, easily lags behind the reality of media practices. Therefore, we will not begin with studies reflecting changes, but rather by revisiting the era of mass media literacy in policies, asking how media literacy and education policies have been constructed over time, with a long-lasting effect on contemporary societies. The issue includes six research articles from Finland, the Baltic countries, Poland, and Russia. At the end of the issue, there are book reviews assessing some recent academic literature on media literacy, aiming to place this literature in global and local contexts. The two first articles of this special issue consider how policies have constructed the discourses around media education in national policy frameworks. In the first article, Lauri Palsa and Saara Salomaa present a frame analysis of policy documents concerning media education in Finland. While Finland has become the forerunner in media education, its neighbor Estonia has taken a world-leading position in e-governance and the information society. In the second article, Kertti Merimaa and Krista Lepik inquire into the concept of information literacy in policy documents in Estonia.

As important as it may be to push media literacy to the political agenda so that it can be embedded in the activities of formal institutions, it is equally important to convince the objects and subjects of media education of the importance of the issue so that they can better inform and educate themselves on the subject. The third article approaches policy by asking how people assess the importance and relevance of media and information literacy in society. Anda Rožukalne, Ilva Skulte, and Alnis Stakle present the results from a survey examining citizens' perceptions of media literacy in the context of Latvia.

The next three articles deal with the mixed modes of communication that have given rise to forms of literacy in which the assessment of credibility and the factual basis of messages stay in focus. Michał Kuś and Paulina Barczyszyn-Madziarz present an exploratory study of the emerging fact-checking scene in Poland, tracing the educational potential of the existing initiatives in the country. Andrius Šuminas and Deimantas Jastramskis examine Lithuanian students' skills to assess credibility 
in online news texts as part of news literacy. The last article brings us closer to the digital reality in which mash-up genres, such as memes, require new types of literacy: Svetlana Shomova demonstrates, with the help of Russian students interpreting viral images adopting elements of news discourse, how meme literacy makes an important case in media literacy.

The special issue concludes with an interview with Grzegorz Ptaszek, the current president of the Polish Association of Media Education. The association was launched in 2012 at the initiative of academics and practitioners and in response to a need that was precipitated by political decisions. The establishment of a national association was, more precisely, to counteract the measures by the Ministry of National Education in 2009 in Poland to not integrate media education in the national core curriculum, despite the preceding urges by the European Union to include media literacy in national policy agendas (see e.g., European Parliament, 2008). Brosch (2017, p. 311) concluded that the decision to eliminate media education "drastically limited media education" and restricted it to "IT skills and reception of ICT messages." According to Gzregorz Ptasek, media educators thus have an important mission to promote approaches to media literacy that are more attached to critical thinking.

On behalf of the project group, I want to thank the European Journal of Communication and its publisher, the Polish Communication Association, for providing us the possibility to put together a special issue on media literacy. We are grateful for all the constructive support that our partners, reviewers, and experts have provided along the way. In particular, we want to thank Bogusława Dobek-Ostrowska for her acknowledgement of the importance and relevance of the topic to the academic community around the Baltic Sea and for opening up the discussion with the publication of this special issue. The editorial team of CEJC, under the lead of Michał Głowacki, also deserves our warmest thanks, in particular, the journal editor Agnieszka Stępińska. We also want to thank the partners, the Latvian News Agency LETA and the National Library of Latvia, for a fruitful collaboration during the MIL+LAB project. Finally, my own affiliation, Nordicom, the Centre for Nordic Media Research at the University of Gothenburg in Sweden, is pleased to have been involved as a partner in this project.

\section{REFERENCES}

Aufderheide, P. \& Firestone, C. (1993). Media literacy: A report of the national leadership conference on media literacy. Aspen Institute.

Brosch, A. (2017). Media education in Poland: Needs versus reality. Journal of Technology and Information Education, 9(1), 307-317. http://doi.org/10.5507/jtie.2017.030.

Bruns, A. (2016). User-generated content. In K.B. Jensen, R.T. Craig, J.D. Pooley, \& E.W. Rothenbuhler (Eds.), The international encyclopedia of communication theory and philosophy (pp. 1-5). WileyBlackwell.

Buckingham, D. (Ed.) (1990). Watching media learning: Making sense of media education. Routledge.

Buckingham, D. (2019). The media education manifesto. Polity Press. 
Cabinet of Ministers of Latvia (2018). Noteikumi par valsts pamatizglitïbas standartu un pamatizglitiibas programmu paraugiem [Regulations on the national standard for basic education and models of basic education programs]. https://likumi.lv/ta/id/303768.

Carlsson, U. (Ed.) (2019). Understanding media and information literacy (MIL) in the digital age: A question of democracy. University of Gothenburg.

De Abreu, B.S., Mihailidis, P., Lee, A.Y.L., Melki, J., \& McDougall, J. (2017). Arc of research and central issues in media literacy education. In B.S. De Abreu, P. Mihailidis, A.Y.L. Lee, J. Melki, \& J. McDougall, J. (Eds.), International handbook of media literacy education (pp. 1-15). New York: Routledge.

Del Mar Grandío, M., Dilli, S., \& O’Neill, B. (2017). Legal frameworks for media and information literacy. In D. Frau-Meigs, I. Velez, \& F.J. Michel (Eds.). Public policies in media and information literacy in Europe: Cross-country comparisons (pp. 116-129). Routledge.

Einstein, M. (2016). Black-op advertising: Native ads, content marketing, and the covert world of the digital sell. OR Books.

Estonian Youth Work Centre (2013). Youth field development plan 2014-2020. https://www.hm.ee/sites/ default/files/nak_eng.pdf.

European Parliament (2008). European Parliament resolution of 16 December 2008 on media literacy in a digital world, 2008/2129 (INI). https://op.europa.eu/en/publication-detail/-/publication/aa25676ba98c-4f30-b813-698fa076d035/language-en.

European Parliament and the European Council (2018). Directive 2018/1808 of the European Parliament and of the Council of the European Union (Audiovisual Media Services Directive.) https://eur-lex. europa.eu/eli/dir/2018/1808/oj.

Fedorov, A. (2002). Media education in secondary schools in Russia. In A. Hart \& D. Süss (Eds.), Media education in European countries: A comparative study of teaching media in mother tongue education in secondary schools (pp. 99-110). The Swiss Federal Institute of Technology Zurich.

Fedorov, A. (2008). On media education. ICOS UNESCO IFAP.

Fedorov, A. (2009). Media education in Russia: A short history. In M. Leaning (Ed.) Issues in information and media literacy: Criticism, history and policy (pp. 167-188). Informing Science Press.

Fedorov, A. (2013). Russian media educators: Case studies portraits. European Researcher, 59(9-2), 2316-2330. http://dx.doi.org/10.2139/ssrn.2625017.

Finnish National Agency for Education (2004). Perusopetuksen opetussuunnitelman perusteet [The core curriculum for basic education]. https://www.oph.fi/sites/default/files/documents/perusopetuksenopetussuunnitelman-perusteet_2004.pdf.

Finnish National Agency for Education (2014). Perusopetuksen opetussuunnitelman perusteet [The core curriculum for basic education]. https://www.oph.fi/sites/default/files/documents/perusopetuksen_opetussuunnitelman_perusteet_2014.pdf.

Finnish National Agency for Education (2018). Varhaiskasvatussuunnitelman perusteet [The national core curriculum for early childhood education and care]. https://www.oph.fi/sites/default/files/ documents/varhaiskasvatussuunnitelman_perusteet.pdf.

Finnish National Agency for Education (2019). Lukion opetussuunnitelman perusteet [The core curriculum for upper secondary school]. https://www.oph.fi/sites/default/files/documents/lukion_opetussuunnitelman_perusteet_2019.pdf.

Frau-Meigs, D. (2007). Cultural diversity and global media studies. Global Media and Communication, 3(3), 260-266. https://doi.org/10.1177/17427665070030030104.

Frau-Meigs, D. (2012). Transliteracy as the new research horizon for media and information literacy. Media Studies, 3(6), 14-26.

Frau-Meigs, D., \& Torrent, J. (Eds.) (2009). Mapping media education policies in the world: Visions, programmes and challenges. UNESCO.

Frau-Meigs, D., Velez, I., \& Michel, J.F. (Eds.) (2017). Public policies in media and information literacy in Europe: Cross-country comparisons. Routledge. 
Government Offices of Sweden (2018). Strategi för en stark demokrati - främja, förankra, försvara [A strategy for a strong democracy - to promote, anchor, defend]. https://www.regeringen.se/49f2a8/conte ntassets/64308b0cc8a14ddb8532ff541369c602/strategi-for-en-stark-demokrati---framja-forankraforsvara.pdf.

Grizzle, A., \& Hamada, M. (2019). Media and information literacy expansion (MIL ${ }^{\mathrm{x}}$ ): Reaching global citizens with MIL and other competencies. In U. Carlsson (Ed.), Understanding media and information literacy (MIL) in the digital age: A question of democracy (pp. 241-261). Gothenburg: University of Gothenburg.

Huovinen, J. (2019). Miten toimittaja näkee itsensä mediakasvattajana - Faktana, kiitos -koulukiertueen toimittajien näkökulmia mediakasvatukseen [How the journalist views him- or herself as a media educator: Perspectives on media education from the journalists involved in the "Facts please" school visit tourney]. Oulu University of Applied Sciences.

Ilomäki, L., Paavola, S., Lakkala, M., \& Kantosalo, A. (2016). Digital competence - an emergent boundary concept for policy and educational research. Education and Information Technologies, 21(3), 655-679. https://doi.org/10.1007/s10639-014-9346-4.

Kakkola, A. (2009). "Mä en oo pedagogiikan ammattilainen, eikä mua saa sellasena pitää." Haastattelututkimus mediakasvatuksesta osana toimittajan työtä ["I'm not a professional in pedagogy, and you shall not regard me as a such." An interview study on media education as part of the journalists' work]. University of Tampere.

Kotilainen, S., \& Kupiainen, R. (2014). Media and information literacy policies in Finland. University of Tampere.

Kõuts-Klemm, R., Harro-Loit, H., Ibrus, I., Ivask, S., Juurik, M., Jõesaar, A., Järvekülg, M., Kauber, S., Koorberg, V., Lassur, S., Loit, U., \& Tafel-Viia, K. (2019). Meediapoliitika olukorra ja arengusuundade uuring [A study on the state and trends of media policy]. University of Tartu and University of Tallinn.

Lauha, H., \& Tuominen, S. (2018). Kohti digitaalista nuorisotyötä. Helsinki: Verke. https://www.verke. org/wp-content/uploads/2016/10/Kohti-digitaalista-nuorisotyota-1.pdfv.

Lessenski, M. (2019). Just think about it: Findings of the Media Literacy Index 2019. Open Society Institute.

Lithuanian Journalism Centre (2019). Map of Internet: An online media literacy tool for teachers. https://lzc.lt/leidiniai/interneto-zemelapis-interneto-mediju-rastingumo-metodologine-priemonemokytojams/.

Livingstone, S. (2004). What is media literacy? Intermedia, 32(3), 18-20.

McDougall, J. (2017). Media literacy for good agency: If Jez we could. Journal of Media Literacy, 64(1-2), $20-26$.

Ministry of Education and Research in Estonia (2014). National curricula 2014. https://www.hm.ee/en/ national-curricula-2014.

Ločmele, K. (2019, January 2). Media literacy in Latvia: The Ministry of Culture's 6 strands. Media \& Learning News. https://news.media-and-learning.eu/type/featured-articles/media-literacy-inlatvia-the-ministry-of-cultures-6-strands/.

Masterman, L. (1985). Teaching the media. Comedia Publishing Group.

Merrin, W. (2014). Media studies 2.0. Routledge.

Ministry of Communications and Mass Media of the Russian Federation (2014). Prikaz Minkomsvyazi Rossii "O provedenii otkrytogo konkursa na pravo zakljucheniya gosudarstvennogo kontrakta na vypolnenie nauchno-issledovatelskoj raboty po teme: "Otsenka tekyshchego sostoyaniya i perspektiv izmeneniya urovnya mediagramotnosti naseleniya Rossijskoj Federatsii na osnove natsionalnogo monitoringa mediapovedeniya" [On holding an open competition for the right to conclude a state contract for the implementation of a study on the topic: "Assessing the current status and prospects of changing the level of media literacy of the population of the Russian Federation based on national monitoring of media behavior"]. Order No. 260 of August 26, 2014. https://digital.gov. $\mathrm{ru} / \mathrm{ru} /$ documents/4314/. 
Ministry of Culture and Education in Finland (2013). Hyvä medialukutaito: suuntaviivat 2013-2016 [Good media literacy: guidelines 2013-2016]. http://julkaisut.valtioneuvosto.fi/handle/10024/75278 Ministry of Culture and Education in Finland (2019). Media literacy in Finland: National media education policy. https://medialukutaitosuomessa.fi/mediaeducationpolicy.pdf.

Ministry of Culture in Latvia (2016). Mass media policy guidelines of Latvia 2016-2020. https://likumi.lv/ ta/en/id/286455-mass-media-policy-guidelines-of-latvia-2016-2020.

Ministry of Culture in Sweden (2018). Kommittédirektiv: nationell satsning på medie- och informationskunnighet och det demokratiska samtalet [Committee directive: National investment in media and information literacy and the democratic dialogue]. https://www.regeringen.se/4a51c3/contentassets/a10dd72d5c474467ab1937bb52aac6ec/nationell-satsning-pa-medie--och-informationskunnighet-och-det-demokratiska-samtalet-dir-201888.pdf.

Ministry of Culture of the Republic of Lithuania (2019). Issakymas dèl visuomenès informavimo politikos strateginių krypčių 2019-2022 metams patvirtinimo [Strategic guidelines for media policy 2019-2022]. https://www.e-tar.lt/portal/lt/legalAct/95c4cf60344211e99595d005d42b863e.

Ministry of Digital Development, Communications and Mass Media of the Russian Federation (2019). Novyye standarty $v$ obrazovanii [On media literacy criteria and methods for assessing the level of media literacy of the population]. https://digital.gov.ru/ru/activity/directions/403/.

Ministry of Education and Research in Estonia (2020). Meediapädevuse nädal 2020 [Media competence week]. https://www.hm.ee/et/MPN.

Ministry of Education and Science in Lithuania (2017). Isakymas del 2017-2018 ir 2018-2019 mokslo metu pagrindinio ir vidurinio ugdymo programu bendruju ugdymo planu patvirtinimo [Order of the Minister of Education and Science of the Republic of Lithuania No V-442, June 5, 2017, concerning the approval of the general curricula for the 2017-2018 and 2018-2019 school years for basic and secondary education]. https://www.e-tar.lt/portal/lt/legalAct/3946370049e911e7846ef01bfffb9b64/ asr.

Ministry of Funds and Regional Policy in Poland (2014). Operational programme: Digital Poland for 2014-2020 https://www.polskacyfrowa.gov.pl/media/10410/POPC_eng_1632015.pdf.

Ministry of National Education in Poland (2017). Rozporzadzenie $z$ dnia 24 lutego 2017 r. w sprawie podstawy programowej wychowania przedszkolnego oraz podstawy programowej ksztatcenia ogólnego dla szkoly podstawowej [Ordinance of May 30, 2014 Concerning the National Curriculum for Preprimary and General Education in All School Types]. http://prawo.sejm.gov.pl/isap.nsf/download. xsp/WDU20170000356/O/D20170356.pdf.

Modern Poland Foundation (2020). Educacja medialna [Media education]. https://edukacjamedialna. edu.pl.

NAMLE, National Association for Media Literacy Education (2020). Media literacy defined. https:// namle.net/publications/media-literacy-definitions/.

The New London Group (1996). A pedagogy of multiliteracies: Designing social futures. Harvard Educational Review, 66(1), 60-93. https://doi.org/10.17763/haer.66.1.17370n67v22j160u.

Palsa, L., Pääjärvi, S., Tossavainen, T., \& Pekkala, L. (2014). Mediakasvatushankkeet 2009-2014: selvitys opetus- ja kulttuuriministeriön hallinnonalalla rahoitetuista hankehakemuksista [Media education projects 2009-2014: A report of project proposals financed by the sector of the Ministry of Education and Culture]. National Audiovisual Institute.

Park, M.-J., \& Curran, J. (Eds.) (2000). De-westernizing media studies. Routledge.

Pedtehno - Sovremennyye pedagogicheskiye (obrazovatel'nyye) tekhnologii (2016). Mediaobrazovanie $v$ shkole. https://pedtehno.ru/content/mediaobrazovanie-v-shkole.

Ptaszek, G., \& Lysik, M. (2018). Media literacy in Poland. In Hobbs, R., \& Mihaidilis, P. (Eds.) International encyclopedia of media literacy. Wiley-Blackwell.

Rasi, P., Kangas, M., \& Ruokamo, H. (2019). Promoting multiliteracy in the Finnish educational system. In M. Paksuniemi \& P. Keskitalo (Eds.), Introduction to the Finnish educational system (pp. 96-157). Brill/Sense.

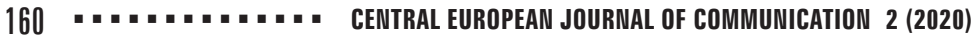

Central European Journal of Communication Volume 13, No 2 (26), Special Issue 2020

(C) for this edition by CNS 
Salomaa, S., Palsa, L., \& Malinen, V. (2017). Opettajaopiskelijat ja mediakasvatus [Teacher students and media education]. National Audiovisual Institute.

State Police of Latvia (2018). Supervaroni interneta [The superheroes of the internet]. http://vp.gov.lv/ supervaronis/.

Star, S.L., \& Griesemer, J.R. (1989). Institutional ecology, "translations" and boundary-objects: Amateurs and professionals in Berkeley's Museum of Vertebrate Zoology, 1907-39. Social Studies of Science, 19(3), 387-420. https://doi.org/10.1177/030631289019003001.

Stordy, P. (2015). Taxonomy of literacies. Journal of Documentation, 71(3), 456-476. https://doi. org/10.1108/JD-10-2013-0128.

The Swedish Media Council (2019). MIK för framtida lärare och bibliotekarier: medie- och informationskunnighet inom lärarutbildningarna i svenska, samhällskunskap och bild samt biblioteks- och informationsvetenskap - en enkätundersökning [MIL for future teachers and librarians: Media and information literacy in Swedish teacher's education, social sciences and visual studies as well as librarian and information science - a survey]. https://statensmedierad.se/download/18.1094e1d11 6a796020d51eafa/1556880737643/MIK\%20för\%20framtida\%20lärare\%20och\%20bibliotekarier. pdf.

The Swedish National Agency for Education (2018). Curriculum for the compulsory school, preschool class and school-age educare. https://www.skolverket.se/publikationsserier/styrdokument/2018/curriculum-for-the-compulsory-school-preschool-class-and-school-age-educare-revised-2018?id=3984

The Swedish National Agency for Education (2019). Curriculum for the upper secondary school. https:// www.skolverket.se/publikationer?id=2975.

The Swedish Press and Broadcasting Authority and the Swedish Media Council (2017). Kartläggning av insatser som syftar till stärkt medie- och informationskunnighet [A mapping of contributions to strengthened media and information literacy]. https://www.mprt.se/documents/uppdrag/kartläggning\%20av\%20insatser\%20som\%20syftar\%20till\%20stärkt\%20medie-\%20och\%20informationskunnighet.pdf.

Toffler, A. (1980). The third wave. Collins.

Tyner, K. (1998). Literacy in a digital world: Teaching and learning in the age of information. Lawrence Erlbaum Associates.

Ugur, K., \& Harro-Loit, H. (2010). Media literacy in the Estonian national curriculum. In S. Kotilainen, \& S.-B. Arnolds-Granlund (Eds.), Media literacy education: Nordic perspectives (pp. 133-144). Nordicom.

UNESCO (1983). The Grünwald declaration on media education. Educational Media International, 20(3), 26.

UNESCO (2013). Global media and information literacy assessment framework: Country readiness and competencies. UNESCO.

UNESCO (2015). Paris declaration on media and information literacy in the digital age. UNESCO. www.unesco.org/new/fileadmin/MULTIMEDIA/HQ/CI/CI/pdf/news/paris_mil_declaration.pdf

Wenger, E. (1998). Communities of practice: Learning, meaning and identity. Cambridge University Press. https://doi.org/10.1017/CBO9780511803932. 